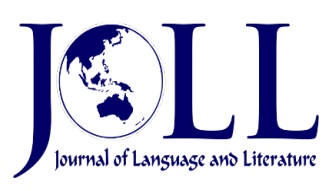

Vol. 21 No. 1, April 2021, pp. 172 - 189

DOI: 10.24071/joll.v21i1.3035

Available at https://e-journal.usd.ac.id/index.php/JOLL/index

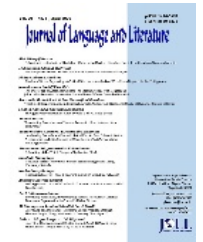

This work is licensed under a Creative Commons Attribution-ShareAlike 4.0 International License.

\title{
The Metaphoric Conceptualization of the Covid-19 Pandemic in the Online Press Releases of Lapor Covid-19 and Kominfo
}

\author{
Maria Magdalena Sinta Wardani \\ mmsintawardani@usd.ac.id \\ Faculty of Letters, Sanata Dharma University, INDONESIA
}

\begin{abstract}
This article seeks to describe the metaphoric conceptualization of the COVID19 pandemic in the online press releases of Lapor COVID-19 and the Ministry of Communication and Information Technology (Kominfo). More specifically, it seeks to 1) describe the metaphorical linguistic forms contained in the online press releases of Lapor COVID-19 and Kominfo, 2) identify the conceptual metaphors contained in the online press releases of Lapor COVID-19 and Kominfo, 3) describe the function of the metaphors contained in the online press releases of Lapor COVID-19 and Kominfo. Data were collected between March 1 and October 31, 2020. Analysis was conducted using the method developed by Steen (2009). Nine metaphors were identified as being used within the context of the COVID-19 pandemic: 1) berguguran ('fall in battle'), 2) berdamai ('make peace'), 3) garis depan ('frontlines'), 4) melawan ('oppose'), 5) menang ('win'), 6) benteng ('fortress, bastion'), 7) menghantui ('spook'), 8) membesar ('grow in size'), and 9) menelan ('swallow'). Three conceptual metaphorizations of the pandemic were utilized by Lapor COVID-19, namely 1) PANDEMIC IS WAR, 2) PANDEMIC IS GHOST/SPECTER, and 3) PANDEMIC IS MONSTER. Meanwhile, one conceptual metaphorization was identified in Kominfo's press releases: PANDEMIC IS WAR. These conceptual metaphors' selection was informed by the genre of the discourses as well as specific characteristics of the institutional. Metaphors, as rhetoric devices in persuasive discourses, function to 1) increase the attractiveness of the message and stimulate readers' imagination, 2) reduce the complexity of the message, and 3) to concretize the discourse.
\end{abstract}

Article

information

Keywords: press release; conceptual metaphor; pandemic; COVID-19; persuasive discourse 


\section{Introduction}

The ongoing COVID-19 pandemic has become a global issue, one that has drastically transformed diverse aspects of human life. This has included communication patterns, as the pandemic has necessitated efficient public communication to ensure that accurate information is spread throughout all elements of society. As stated by Syaipudin (2020, p. 14), to overcome the various problems created by the COVID-19 pandemic, public communication is the best means of maintaining social interactions.

The various stakeholders involved in efforts to control the COVID-19 pandemic in Indonesia have similarly required public communication to ensure that the public receives accurate information and targeted guidance, as only then can people understand their situation and adapt to it, thereby curbing the spread of the novel coronavirus. Online media have become increasingly strategic as public communication patterns have shifted; any information posted online can be rapidly accessed and utilized by the public. It is this consideration that underpins the current study of online press releases regarding COVID-19 and its mitigation. The press releases discussed in this study have been published online by stakeholders in Indonesia's ongoing efforts to eradicate COVID-19.

As stated above, this study will examine the press releases of two stakeholders: first, the Ministry of Communication and Information Technology (Kementerian Komunikasi dan Informatika, Kominfo), a government agency that shares official information; and Lapor COVID-19, an organization that presents itself as a forum for citizen reporting and is used to share information that (is perceived as) being ignored by the government. These institutions represent two sides of the same coin, and thus are interesting to examine in conjunction.

It is necessary to utilize easily understood language to conveying messages. According to Syaipudin (2020, p. 14), the ability of the recipient to receive and understand the message is central to the communication process. As such, clear and simple language is necessary to convey messages to the masses and ensure that these messages are understood by recipients, no matter their individual characteristics and sensitivity. Individuals' diverse abilities must be considered when encoding messages. It may thus be concluded that simplicity and clarity are the cornerstones of mass communication.

This study examines the use of metaphoric language in online press releases, under the assumption that these metaphors serve a specific function within persuasive discourses. It is relatively easy to identify such metaphoric expressions in coverage of the ongoing pandemic. Take the following example, an excerpt from a Kominfo press release.

\section{Gelar Lebaran Virtual, Kominfo Ajak Masyarakat Berdamai dengan Pandemi COVID-19}

Holding Eid Virtually, Kominfo Invites the Public to Make Peace with the COVID-19 Pandemic

(Source: https://www.kominfo.go.id)

In this title, the word berdamai ('make peace') is a metaphor. In the body of this press release, the metaphoric meaning of the word berdamai is clarified in order to prevent miscommunication and minimize divergent understandings.

Saya ingin menekankan bahwa berdamai bukan berarti menyerah. Berdamai adalah menyesuaikan diri dengan kedisiplinan yang tinggi untuk menjalankan protokolprotokol kesehatan sebagai upaya untuk memutus mata rantai penyebaran COVID19.

I want to emphasize that making peace is not surrendering. To make peace is to adapt oneself to health protocols, with a high level of discipline, and thus break the transmission chain of COVID-19.

(Source: https://www.kominfo.go.id)

The word berdamai is immediately contrasted with the word menyerah (surrender) through negation. The government uses the word bukan to distinguish berdamai from menyerah, thereby 
attempting shape public opinion by creating a persuasive discourse.

Metaphors may be classified as persuasive devices that function to stimulate the creativity and imagination of audiences (Kristina, 2017, pp. 91-95). According to Courtright and Smudde (2009, p. 154), persuasion is often identified with public relations. Press releases, meanwhile, are persuasive discourses that are used for public relations. Such releases trace their roots to journalists' entry into public relations, when they began presenting their clients and organizations using a seemingly objective approach built around the inverted pyramid structure (Courtright and Smudde, 2009, p. 149).

Courtright and Smudde (2009, p. 149153 ) identify five elements that shape press releases and public relations. First, there exist different types of discourses or genres, which emerge as a natural consequence of commonalities that require specific symbols and responses. Second, form follows function; the type of discourse is determined not by convention, but rather the rhetoric strategies that are "given voice" (used to convey a message). Third, bilateral communication is necessary; when designing a strategic response, organizations must not simply respond to situations, but consider how audiences perceive said situations and the responses expected of them. Fourth, stability and flexibility; public relations staff must not only know the conventional characteristics of discourses, but also recognize the extent of their freedom. Some genres allow extraordinary levels of creativity, while others (especially those favored by government agencies) limit the available strategies. Fifth, adaptation is inevitable; discourse conventions change over time, along with audience responses and organizational needs. Further adaptation is driven by new media channels, which may be more user-friendly and require new approaches.

As mentioned above, the COVID-19 pandemic has instigated unprecedented transformations in global society. This study will examine how the pandemic is conceptualized by society, realizing this goal based on the metaphors used to describe it. Before analysis, it is thus necessary to elucidate on the concept of metaphor, which is commonly used in cognitive linguistics.

In cognitive linguistics, metaphors are understood as the main operational framework for human though. According to Lakoff (1981, p. 5), metaphors' existence as linguistic units is only made possible by the presence of conceptual metaphors; as such, understanding requires a consideration of both metaphoric words and concepts. In essence, metaphors are means of understanding and experiencing situations and conditions relative to others. Metaphors enable individuals to combine existing ideas, and even to create new ones.

According to Lakoff (1981), although metaphors have traditionally been perceived as limited to poetics, contemporary studies have understood them as existing in everyday communication. Metaphors occupy a primary position in everyday communication, as through them human cognitive processes are operated and experiences are understood. Lakoff (1981, p. 3) writes that communication relies on a shared system of concepts and behaviors, and language offers an effective means of exploring this system. In other words, it is possible to recognize cognitive metaphors through a systematic and evidencebased investigation of linguistic forms and metaphors.

One such approach is offered by Steen (2007), who seeks to bridge the gap between linguistic and conceptual metaphors through a five-stage analysis. This approach offers a promising means of identifying the conceptual metaphors within a discourse. Steen writes that, although indirectness facilitates the identification of metaphors, it is not sufficient in and of itself. Metaphors are created through the sharp distinction and contrast of multiple conceptual domains, which are linked by various forms of semantic transfer that are built on a foundation of similarity. This distinguishes metaphors from other forms of indirect expression; metonyms, for instance, also contrast two domains, but on a basis of contiguity (Steen, 2007, p. 10). 
Even when language is used directly, it may still be metaphoric at the conceptual level. In such cases, identifying the conceptual metaphors involved is problematic. Steen's method facilitates the identification of words that are used metaphorically in discourses, thereby enabling researchers to identify conceptual metaphors within discourses based on the linguistic metaphors contained within them.

One study of metaphors in persuasive texts was conducted by Boeynaems et al. (2017), who investigated the metaphoric expressions (both conventional and novel) and non-metaphoric expressions used in news texts to influence audiences' views. Conventional metaphors follow conventional frameworks in mapping issues, and thus facilitate the concretization and understanding of relevant issues. Their usage, as such, can positively influence individuals' cognitive perception of the message being communicated by increasing the quality of arguments and reducing the complexity of messages. The researchers assumed that, where conventional metaphors positively influence audiences' perception of the text, they will influence audiences' opinions and perspectives. Novel metaphors may similarly cultivate a positive response to the message, as they can increase audiences' interest and stimulate their imaginations. In this, the researchers assume that, through the mechanisms inherent to the text, novel metaphors can influence audiences' opinions and perspectives of messages (Boeynaems, Burgers, Konijn, and Steen, 2017, p. 2866).

In their study, Boeynaems et al. (2017) used a dictionary to identify metaphors. If a metaphor's contextual meaning could be identified through the dictionary, it was identified as a conventional metaphor. Conversely, if the contextual meaning of the metaphor was not found within the dictionary, it was identified as a novel metaphor (Boeynaems, Burgers, Konijn, and Steen, 2017, p. 2866). To determine the strength of such metaphoric expressions, the researchers relied on the Google search engine to ascertain their relative frequency.
This study found that metaphors operate through diverse mechanisms that follow two distinct perceptual routes. Through the first mechanism, which stems from perceived innovation, novel metaphors can positively influence how texts are affectively and cognitively perceived. Through the second mechanism, which stems from perceived appropriateness, novel metaphors negatively influence the cognitive perception of the text.

Haula and Nur (2019), seeking to reveal the types of conceptual metaphors employed, investigated how metaphors are conceptualized in the opinion column of the Indonesian daily Kompas. They found that writers tended to transfer their ideas from the abstract to the concrete, from the ideal to the physical. Many used metaphors that were associated with nature, including karam ('to sink'), tumbang ('to fall'), sapuan badai ('storm-swept'), berladang ('to farm'), and bertiup ('to blow'). The images created through these metaphors were predominantly associated with the concept of existence.

Both studies examine the use of metaphors within news stories. Where the first study sought to prove its hypothesis regarding the influence of metaphors on audience perceptions, the second study analyzed opinion pieces and editorials to explore their conceptual metaphors. Unlike these previous studies, the current article investigates the linguistic and metaphoric concepts contained within the persuasive texts published on the official websites of Lapor COVID-19 and Kominfo. It also seeks to understand these metaphors' function as rhetoric devices.

\section{Methodology}

This research began with data collection, which relied on the observation method and the note-taking technique. During the data collection, metaphoric words related to COVID-19 were identified through observation and then recorded.

The data were collected from press releases related to COVID-19 issued by Lapor COVID-19 through laporcovid19.org and by Kominfo through kominfo.go.id. Lapor COVID19 was selected to represent a private 
organization intended to voice the interests of the public, while Kominfo was chosen to represent the pandemic-related information and policies disseminated by the government. The data were collected from press releases issued between March 1 and October 31, 2020. After data were collected, it was found that five press releases issued by Lapor COVID-19 and six press releases issued by Kominfo included metaphoric elements in their conceptualization of the pandemic.

The data were subsequently analyzed. Analysis began with the identification of linguistic metaphors; further analysis was conducted subsequently to identify the conceptual metaphors contained within the texts. An analysis was conducted using the five-stage method developed by Steen (2009, p. 206), i.e. 1) the identification of metaphorrelated words, 2) the identification of propositions, 3) the identification of open comparisons, 4) the identification of analogical structures, and 5) the identification of crossdomain mapping. For the first stage, the researcher consulted the fifth edition of the Great Dictionary of the Indonesian Language (Kamus Besar Bahasa Indonesia, KBBI) to ascertain the basic meaning and contextual meaning of words that were suspected to be related to metaphors. Complementary information was collected through an informal search, using Google, which enabled the researcher to ascertain whether these words were metaphoric expressions.

The identity method was used to identify and describe linguistic metaphors. Foundational to this method was the determination of defining elements, through which mental, referential, articulatory, translational, orthographic, and pragmatic elements were identified (Sudaryanto, 2015, p. 25). This enabled the researcher to map linguistic units based on their specific referents. Also used was the equalizing technique, which enabled the researcher to identify the link between the source and target expression. The results of this analysis are presented formally and informally, both through tables and through description.

\section{Results and Discussion}

\section{The Conceptual Metaphorization of the COVID-19 Pandemic}

Nine metaphors were identified as being used within the context of the COVID-19 pandemic: 1) berguguran ('fall in battle'), 2) berdamai ('make peace'), 3) garis depan ('frontlines'), 4) melawan ('oppose'), 5) menang ('win'), 6) benteng ('fortress, bastion'), 7) menghantui ('spook'), 8) membesar ('grow in size'), and 9) menelan ('swallow'). These data indicate three different conceptual metaphorizations of the pandemic, namely 1) PANDEMIC IS WAR, 2) PANDEMIC IS GHOST/SPECTER, and 3) PANDEMIC IS MONSTER. The metaphor-related words collected from press releases will be analyzed in detail below.

\section{Conceptual Metaphor: "PANDEMIC IS WAR"}

The words berguguran ('fall in battle'), berdamai ('make peace'), garis depan ('frontlines'), melawan ('oppose'), menang ('win'), and benteng ('fortress, bastion') are metaphors. These words (or, to borrow a term from Steen, lexical units) will be analyzed within the conceptual metaphor that "PANDEMIC IS WAR".

\section{Analysis of the word berguguran}

In the first stage of analysis, the basic (denotative) meaning and contextual meaning of words were identified. To identify the basic meaning of the word, the fifth edition of $K B B I$ was consulted. To identify the contextual meaning, the word's relationship with its surrounding linguistic units was examined. Words whose contextual meaning differed from their basic meaning were identified as metaphor-related words. Below are the meanings of the word berguguran.

Basic meaning: 'to die in battle, often in large numbers'

Contextual meaning: 'many healthcare workers have died while treating COVID19 patients'

The presence of the word "battle" in the denotative definition above indicates that the 
basic meaning of berguguran exists within the WAR domain. Further analysis is provided below:

Table 1. Analysis of the Word Berguguran

\begin{tabular}{|c|c|c|}
\hline Text & \multicolumn{2}{|c|}{$\begin{array}{l}\text { LaporCovid19.org, melalui Pusara Digital juga sudah mendokumentasikan } \\
\text { banyaknya tenaga kesehatan yang berguguran selama pandemi ini. } \\
\text { (LaporCovid19.org, through the Digital Database, has documented the amount of } \\
\text { healthcare workers who have fallen in battle during the pandemic.) } \\
\text { (Source: https://laporcovid19.org) }\end{array}$} \\
\hline 1 & $\begin{array}{l}\text { Identification of metaphor- } \\
\text { related words }\end{array}$ & berguguran ('fall in battle') \\
\hline 2 & Identification of propositions & $\begin{array}{l}\text { P1 HEALTHCARE WORKERS HAVE FALLEN IN } \\
\text { BATTLE } \\
\text { P2 TIME P1 DURING THE PANDEMIC } \\
\text { P3 MODIFIER MANY P1 }\end{array}$ \\
\hline 3 & $\begin{array}{l}\text { Identification of open } \\
\text { comparison }\end{array}$ & $\begin{array}{l}\operatorname{SIM}\{\mathrm{F}, \mathrm{x}, \mathrm{y} \\
{[\mathrm{F}(\text { HEALTHCARE WORKERS } \mathrm{y})] \mathrm{t}} \\
[\text { FALL IN BATTLE }(\mathrm{x}, \mathrm{y})] \mathrm{s}\}\end{array}$ \\
\hline 4 & $\begin{array}{l}\text { Identification of analogical } \\
\text { structure }\end{array}$ & $\begin{array}{l}\operatorname{SIM}\{\mathrm{F}, \mathrm{x}, \mathrm{y} \\
\text { [DIE (HEALTHCARE WORKERS)] t } \\
\text { [FALL IN BATTLE (SOLDIERS)] s } \mathrm{s}\end{array}$ \\
\hline 5 & $\begin{array}{l}\text { Identification of cross-domain } \\
\text { mapping }\end{array}$ & $\begin{array}{l}\text { target }<\text { source } \\
\text { DIE }<\text { FALL IN BATTLE } \\
\text { HEALTHCARE WORKERS }<\text { SOLDIERS } \\
\text { COVID-19 < ENEMY } \\
\text { inference } \\
\text { PANDEMIC IS WAR }\end{array}$ \\
\hline
\end{tabular}

From this analysis, it can be ascertained that the metaphor berguguran ('to fall in combat') infers the idea of "PANDEMIC IS WAR"

\section{Analysis of the word berdamai}

The meanings of the word berdamai ('make peace') are provided below.

Basic meaning: 'to reconcile after a period of enmity' Contextual meaning: 'to adapt one's behavior to new healthcare protocols to stop the spread of COVID-19'

Again, the basic meaning shows that the word berdamai ('make peace') exists within the WAR domain. This is reinforced by the usage example provided in the fifth edition of KBBI: "Kedua negara yang berperang itu telah berdamai" (The two warring nations have made peace.) This example underscores that the word berdamai exists within the WAR domain. Analysis is provided below: 
Table 2. Analysis of the Word Berdamai

\begin{tabular}{|c|c|c|}
\hline Text & \multicolumn{2}{|c|}{$\begin{array}{l}\text { Melihat dinamika ini, Pemerintah Indonesia telah meminta masyarakat untuk mengubah } \\
\text { perilaku dan menyesuaikan diri dengan berdamai dengan virus korona baru ini. } \\
\text { (Seeing these dynamics, the Indonesian Government has asked people to change their } \\
\text { behavior and adapt themselves by making peace with the novel coronavirus). } \\
\text { (Source: https://laporcovid19.org) }\end{array}$} \\
\hline 1 & $\begin{array}{l}\text { Identification of metaphor- } \\
\text { related words }\end{array}$ & berdamai ('make peace') \\
\hline 2 & Identification of propositions & $\begin{array}{l}\text { P1 SEEING THESE DYNAMICS } \\
\text { P2 THE INDONESIAN GOVERNMENT HAS ASKED } \\
\text { PEOPLE } \\
\text { P3 TO CHANGE THEIR BEHAVIOR } \\
\text { P4 ADAPT THEMSELVES (PEOPLE) } \\
\text { P5 MAKING PEACE (PEOPLE) WITH CORONAVIRUS } \\
\text { P6 MODIFIER P5 NOVEL }\end{array}$ \\
\hline 3 & $\begin{array}{l}\text { Identification of open } \\
\text { comparison }\end{array}$ & $\begin{array}{l}\operatorname{SIM}\{\mathrm{F}, \mathrm{x}, \mathrm{y} \\
{[\mathrm{F}(\text { SOCIETY WITH CORONAVIRUS })] \mathrm{t}} \\
[\mathrm{MAKE} \text { PEACE }(\mathrm{x}, \mathrm{y})] \mathrm{s}\}\end{array}$ \\
\hline 4 & $\begin{array}{l}\text { Identification of analogical } \\
\text { structure }\end{array}$ & $\begin{array}{l}\operatorname{SIM}\{\mathrm{F}, \mathrm{x}, \mathrm{y} \\
\text { [CHANGE BEHAVIOR (SOCIETY } \\
\text { CORONAVIRUS)] } \mathrm{t} \\
\text { [MAKE PEACE (ENEMY NATION)] s } \mathrm{s}\end{array}$ \\
\hline 5 & $\begin{array}{l}\text { Identification of cross-domain } \\
\text { mapping }\end{array}$ & $\begin{array}{l}\text { target }<\text { source } \\
\text { CHANGE BEHAVIOR }<\text { MAKE PEACE } \\
\text { CORONAVIRUS/COVID-19 }<\text { ENEMY } \\
\text { inference } \\
\text { PANDEMIC IS WAR }\end{array}$ \\
\hline
\end{tabular}

From this analysis, it can be seen that the metaphor berdamai ('make peace') infers the conceptual metaphor "PANDEMIC IS WAR".

\section{Analysis of the word garis depan}

The meanings of the compound word garis depan ('frontlines') are provided below.
Basic meaning: 'a line of defense situated in close proximity the enemy (in battle)' Contextual meaning: 'an area defending against COVID-19; hospital'

Here, the words enemy and battle indicate that the basic meaning of garis depan ('frontlines') exists in the WAR domain. Analysis follows below:

Table 3. Analysis of the Word Garis Depan

Text

Terkait hal ini, pemerintah juga harus memastikan ketersediaan alat pengaman diri yang sesuai standar kepada para nakes yang bertugas di garis depan.

(Regarding this matter, the government must ensure that personal protective equipment that meets relevant standards is available to all health professionals working on the frontlines.)

(Source: https://laporcovid19.org) 


\begin{tabular}{|c|c|c|}
\hline 1 & $\begin{array}{l}\text { Identification of metaphor- } \\
\text { related words }\end{array}$ & garis depan ('frontlines') \\
\hline 2 & Identification of propositions & $\begin{array}{l}\text { P1 ENSURE GOVERNMENT EQUIPMENT } \\
\text { P2 MEETS EQUIPMENT STANDARDS } \\
\text { P3 WORKING HEALTH PROFESSIONALS } \\
\text { P4 PLACE P3 FRONTLINES } \\
\text { P5 MODIFIER P1 MUST }\end{array}$ \\
\hline 3 & $\begin{array}{l}\text { Identification of open } \\
\text { comparison }\end{array}$ & $\begin{array}{l}\operatorname{SIM}\{\mathrm{F}, \mathrm{x}, \mathrm{y} \\
{[\mathrm{F}(\mathrm{HEALTH} \text { PROFESSIONALS }] \mathrm{t}} \\
[\mathrm{DUTY}(\mathrm{x}, \mathrm{y})] \mathrm{s}\}\end{array}$ \\
\hline 4 & $\begin{array}{l}\text { Identification of analogical } \\
\text { structure }\end{array}$ & $\begin{array}{l}\operatorname{SIM}\{\mathrm{F}, \mathrm{x}, \mathrm{y} \\
{[\mathrm{DUTY}(\mathrm{HEALTH} \text { PROFESSIONALS)] t }} \\
{[\text { DUTY (SOLDIERS FRONTLINES)] s } \mathrm{s}}\end{array}$ \\
\hline 5 & $\begin{array}{l}\text { Identification of cross- } \\
\text { domain mapping }\end{array}$ & $\begin{array}{l}\text { target }<\text { source } \\
\text { HOSPITALS }<\text { FRONTLINES } \\
\text { SOLDIERS }<\text { HEALTH PROFESSIONALS } \\
\text { DUTY }<\text { DUTY } \\
\text { inference } \\
\text { PANDEMIC IS WAR }\end{array}$ \\
\hline
\end{tabular}

From this analysis, it can be seen that the metaphor garis depan ('frontlines') infers the conceptual metaphor "PANDEMIC IS WAR".

\section{Analysis of the word melawan}

The word melawan ('oppose') was identified in five press releases on the Kominfo website. Analysis follows:

Basic meaning: 'to face off against during war'

Contextual meaning: 'to prevent, to eradicate'
In should be noted that, in the dictionary, the word melawan ('oppose') is also identified as being used in the context of boxing and wrestling. However, warfare is the first context mentioned. The example provided in the fifth edition of $K B B I$ is similarly located in the war domain: "Mereka tidak sanggup melawan musuh sebanyak itu" (They were incapable of opposing that many enemies.). As such, melawan has the basic meaning 'to face off against during war', which indicates that it exists within the WAR domain. Analysis follows:

Table 4. Analysis of the Word Melawan

\begin{tabular}{|l|l|l|}
\hline Text & $\begin{array}{l}\text { Kiranya benang merah antara ibadah puasa dan Lebaran ini juga sesuai dengan } \\
\text { semangat kita melawan COVID-19 ini, yaitu laku menahan diri, menempa raga, } \\
\text { membersihkan diri, dan pada akhirnya mencapai kemenangan. } \\
\text { (Perhaps the thread uniting the fast and Eid is also suited to our passionate }\end{array}$ \\
\hline 1 & $\begin{array}{l}\text { opposition to COVID-19, enabling us to practice restraint, temper our bodies, } \\
\text { cleanse ourselves, and finally achieve victory). } \\
\text { (Source: https://www.kominfo.go.id) }\end{array}$ \\
\hline 2 & $\begin{array}{l}\text { Identification of metaphor- } \\
\text { related words }\end{array}$ & melawan ('oppose') \\
\hline
\end{tabular}




\begin{tabular}{|c|c|c|}
\hline & & $\begin{array}{l}\text { P2 SUITED P1 OUR PASSION } \\
\text { P3 OPPOSE WE COVID-19 }\end{array}$ \\
\hline 3 & $\begin{array}{l}\text { Identification of open } \\
\text { comparison }\end{array}$ & $\begin{array}{l}\operatorname{SIM}\{F, x, y \\
{[F(U S \text { COVID-19)] t }} \\
[\text { OPPOSE }(x, y)] s\}\end{array}$ \\
\hline 4 & $\begin{array}{l}\text { Identification of analogical } \\
\text { structure }\end{array}$ & $\begin{array}{l}\text { SIM }\{\mathrm{F}, \mathrm{x}, \mathrm{y} \\
\text { ERADICATE (US COVID-19)] t } \\
\text { [OPPOSE (OUR ENEMY)] s } \mathrm{s}\end{array}$ \\
\hline 5 & $\begin{array}{l}\text { Identification of cross- } \\
\text { domain mapping }\end{array}$ & $\begin{array}{l}\text { target }<\text { source } \\
\text { ERADICATE }<\text { OPPOSE } \\
\text { COVID-19 < ENEMY } \\
\text { Inference } \\
\text { PANDEMIC IS WAR }\end{array}$ \\
\hline
\end{tabular}

From this analysis, it may be seen that the metaphor melawan infers the conceptual metaphor PANDEMIC IS WAR.

\section{Analysis of the word menang} follows.

Analysis of the word menang ('win')

Basic meaning: 'defeat enemies, opponents, competitors' Contextual meaning: 'successfully stop and eradicate COVID-19'
In the fifth edition of $K B B I$, the word menang is illustrated through the sentence Dalam perang selalu ada yang kalah dan ada yang menang (In war, there always those who lose and those who win.). This shows that the basic meaning of the word menang exists within the WAR domain. The contextual meaning 'successfully stop and eradicate COVID-19', meanwhile, is evident from the word's interactions with the other elements of the sentence. Analysis follows:

Table 5. Analysis of the Word Menang

\begin{tabular}{|c|c|c|}
\hline Text & \multicolumn{2}{|c|}{$\begin{array}{l}\text { Saya yakin dan percaya, bersama, kita menang dari corona atau COVID-19. } \\
\text { (I am certain and believe that, together, we can win against corona or COVID-19). } \\
\text { (Source: https://www.kominfo.go.id) }\end{array}$} \\
\hline 1 & $\begin{array}{l}\text { Identification of metaphor- } \\
\text { related words }\end{array}$ & menang ('win') \\
\hline 2 & Identification of propositions & $\begin{array}{l}\text { P1 CERTAIN I } \\
\text { P2 BELIEVE I } \\
\text { P3 WIN WE }\end{array}$ \\
\hline 3 & $\begin{array}{l}\text { Identification of open } \\
\text { comparison }\end{array}$ & $\begin{array}{l}\operatorname{SIM}\{F, x, y \\
{[F(W E y)] t} \\
[W I N(x, y)] s\}\end{array}$ \\
\hline 4 & $\begin{array}{l}\text { Identification of analogical } \\
\text { structure }\end{array}$ & $\begin{array}{l}\text { SIM }\{F, x, y \\
\text { SAFE (WE)] t } \\
{[\text { WIN (STATE)] s\}s }}\end{array}$ \\
\hline 5 & $\begin{array}{l}\text { Identification of cross- } \\
\text { domain mapping }\end{array}$ & $\begin{array}{l}\text { target }<\text { source } \\
\text { SAFE }<\text { WIN }\end{array}$ \\
\hline
\end{tabular}




\begin{tabular}{|l|l|l|}
\hline & & COVID-19 < ENEMY \\
Inference \\
PANDEMIC IS WAR
\end{tabular}

From this analysis, it may be seen that the metaphor menang infers the conceptual metaphor PANDEMIC IS WAR.

\section{Analysis of the word benteng}

Analysis of the word benteng ('fortress, bastion') follows below:

Basic meaning: 'a building used to protect or defend against enemy attacks'

Contextual meaning: 'immunity from COVID-19'

From this analysis, it is apparent that the word benteng exists within the WAR domain. This is further evidenced by the example provided in the fifth edition of $K B B I$ : "Hanya yang sempat berlindung di dalam bentenglah yang selamat" (Only those who stayed in the fortress survived). Analysis follows:

Table 6. Analysis of the Word Benteng

\begin{tabular}{|c|c|c|}
\hline Text & $\begin{array}{l}\text { Karena saat ini imunitas tubuh } \\
\text { untuk melawan COVID-19. } \\
\text { (Because, currently, our imm } \\
\text { opposition to COVID-19). } \\
\text { (Source: https://www.kominfo. }\end{array}$ & $\begin{array}{l}\text { menjadi benteng pertahanan utama dari tubuh kita } \\
\text { ane system is our body's primary bastion in our } \\
\text { go.id) }\end{array}$ \\
\hline 1 & $\begin{array}{l}\text { Identification of metaphor- } \\
\text { related words }\end{array}$ & benteng 'bastion' \\
\hline 2 & Identification of propositions & $\begin{array}{l}\text { P1 BE IMMUNITY BASTION } \\
\text { P2 SIGNIFIER P1 CURRENTLY } \\
\text { P3 OPPOSE US COVID-19 }\end{array}$ \\
\hline 3 & $\begin{array}{l}\text { Identification of open } \\
\text { comparison }\end{array}$ & $\begin{array}{l}\operatorname{SIM}\{\mathrm{F}, \mathrm{x}, \mathrm{y} \\
{[\mathrm{F}(\mathrm{IMMUNITY} \mathrm{y})] \mathrm{t}} \\
[\mathrm{BE}(\mathrm{x}, \mathrm{y})] \mathrm{s}\}\end{array}$ \\
\hline 4 & $\begin{array}{l}\text { Identification of analogical } \\
\text { structure }\end{array}$ & $\begin{array}{l}\operatorname{SIM}\{\mathrm{F}, \mathrm{x}, \mathrm{y} \\
\mathrm{BE}(\mathrm{IMMUNITY})] \mathrm{t} \\
[\mathrm{BE}(\mathrm{BASTION})] \mathrm{s}\} \mathrm{s}\end{array}$ \\
\hline 5 & $\begin{array}{l}\text { Identification of cross-domain } \\
\text { mapping }\end{array}$ & $\begin{array}{l}\text { target }<\text { source } \\
\text { IMMUNITY < BASTION } \\
\text { COVID-19 < ENEMY } \\
\text { COVID-19 SPREAD < ENEMY ATTACK } \\
\text { inference } \\
\text { PANDEMIC IS WAR }\end{array}$ \\
\hline
\end{tabular}

From this analysis, it may be seen that the metaphor benteng infers the conceptual metaphor PANDEMIC IS WAR.

\section{Conceptual Metaphor: "PANDEMIC IS GHOST/SPECTER"}

For this category, the word menghantui ('to spook') was the sole metaphor identified. 
This word indicated the conceptual metaphor PANDEMIC IS GHOST/SPECTER. Analysis follows below:
Basic meaning: 'to spook as a ghost/specter' Contextual meaning: 'to cause fear (concern, anxiety); to frighten'

Table 7. Analysis of the Word Menghantui

\begin{tabular}{|c|c|c|}
\hline Text & \multicolumn{2}{|c|}{$\begin{array}{l}\text { Ancaman infeksi COVID-19 juga menghantui para pekerja perkantoran dan industri di } \\
\text { Indonesia. } \\
\text { (The threat of COVID-19 infection continues to spook the office and industrial workers } \\
\text { in Indonesia) } \\
\text { (https://laporcovid19.org) }\end{array}$} \\
\hline 1 & $\begin{array}{l}\text { Identification of metaphor- } \\
\text { related words }\end{array}$ & menghantui 'to spook' \\
\hline 2 & Identification of propositions & $\begin{array}{l}\text { P1 SPOOK COVID-19 WORKERS } \\
\text { P2 PLACE P1 INDONESIA }\end{array}$ \\
\hline 3 & $\begin{array}{l}\text { Identification of open } \\
\text { comparison }\end{array}$ & $\begin{array}{l}\operatorname{SIM}\{\mathrm{F}, \mathrm{x}, \mathrm{y} \\
{[\mathrm{F}(\mathrm{COVID}-19 \text { WORKERS })] \mathrm{t}} \\
[\operatorname{SPOOK}(\mathrm{x}, \mathrm{y})] \mathrm{s}\}\end{array}$ \\
\hline 4 & $\begin{array}{l}\text { Identification of analogical } \\
\text { structure }\end{array}$ & $\begin{array}{l}\operatorname{SIM}\{\mathrm{F}, \mathrm{x}, \mathrm{y} \\
\text { [SHADOW (COVID-19 WORKERS)] t } \\
\text { [SPOOK (GHOST, HUMAN)] s }\}\end{array}$ \\
\hline 5 & $\begin{array}{l}\text { Identification of cross-domain } \\
\text { mapping }\end{array}$ & $\begin{array}{l}\text { target }<\text { source } \\
\text { SHADOW }<\text { SPOOK } \\
\text { COVID-19 UNSEEN }<\text { GHOST UNSEEN } \\
\text { COVID-19 EXPANDING }<\text { GHOST/SPECTER } \\
\text { FOLLOWING } \\
\text { Inference } \\
\text { PANDEMIC IS GHOST/SPECTER }\end{array}$ \\
\hline
\end{tabular}

From this analysis, it is evident that the word menghantui ('to haunt') infers the conceptual metaphor PANDEMIC IS GHOST. In the reviewed discourses, this was the only word referring to this domain. The possible usage of other metaphor-related words was explored using a Google search, which returned the expression "virus korona gentayangan di jalanan di Jakarta" (the coronavirus haunts the streets of Jakarta; source: Vlix.id). The word gentayangan is generally used to describe the behavior of ghosts; in the fifth edition of $K B B I$, the example usage provided is "tersiar kabar bahwa ada arwah yang menggentayangi desa itu" (there spread word that a spirit was haunting the village). It may thus be concluded that PANDEMIC IS GHOST/SPECTER exists as a conceptual metaphor in language.

\section{Conceptual Metaphor: "PANDEMIC IS MONSTER"}

The words membesar ('grown in size') and menelan ('swallow') were identified as metaphors. Analysis of these words cannot be separated, as they are used within the context of the same sentence. These words will be analyzed within the context of the conceptual metaphor PANDEMIC IS MONSTER. These will be analyzed below.

\section{membesar}

Basic meaning: 'to become big; to appear big'

Contextual meaning: 'to spread more broadly' 
menelan

Basic meaning: 'to take (food) through one's throat'

Contextual meaning: 'to consume prey, etc.'

The words membesar and menelan are analyzed together owing to their chronological link. The subject (S), semantically characterized as an actor, will membesar (grow in size) and ultimately menelan (swallow) human beings, the object (0). As such, both membesar and menelan exist within the MONSTER domain. This is also supported by the example usage of menelan provided in the fifth edition of $K B B I$ : "Gambar kepala raksasa menelan bulan" (An image of a monster swallowing the moon).

Table 8. Analysis of the Word Membesar and Menelan

\begin{tabular}{|c|c|c|}
\hline Text & \multicolumn{2}{|c|}{$\begin{array}{l}\text { Ancaman infeksi COVID-19 juga menghantui para pekerja perkantoran dan industri di } \\
\text { Indonesia. } \\
\text { Pandemi COVID-19 terus membesar dan menelan banyak korban jiwa, serta } \\
\text { menimbulkan masalah ekonomi. } \\
\text { (The COVID-19 pandemic continues to grow and swallow victims, as well as to create } \\
\text { economic problems.) } \\
\text { (Source: https://laporcovid19.org) }\end{array}$} \\
\hline 1 & $\begin{array}{l}\text { Identification of metaphor- } \\
\text { related words }\end{array}$ & membesar ('grown in size') and menelan ('swallow') \\
\hline 2 & Identification of propositions & $\begin{array}{l}\text { P1 GROW PANDEMIC } \\
\text { P2 SWALLOW PANDEMIC VICTIMS } \\
\text { P3 CREATE PANDEMIC PROBLEMS } \\
\text { P4 MODIFIER P2 MANY }\end{array}$ \\
\hline 3 & $\begin{array}{l}\text { Identification } \\
\text { comparison }\end{array}$ & $\begin{array}{l}\operatorname{SIM}\{\mathrm{F}, \mathrm{x}, \mathrm{y} \\
{[\mathrm{F}(\mathrm{PANDEMIC} \mathrm{y}) \& \mathrm{~F}(\mathrm{PANDEMIC} \text { VICTIMS })] \mathrm{t}} \\
[\mathrm{GROW}(\mathrm{x}, \mathrm{y})] \& \text { SWALLOW }(\mathrm{x}, \mathrm{y})] \mathrm{s}\}\end{array}$ \\
\hline 4 & $\begin{array}{l}\text { Identification of analogical } \\
\text { structure }\end{array}$ & $\begin{array}{l}\operatorname{SIM}\{\mathrm{F}, \mathrm{x}, \mathrm{y} \\
\text { [EXPAND (PANDEMIC) \& } \text { KILL (PANDEMIC } \\
\text { VICTIMS)] } \mathrm{t} \\
\text { [GROW (MONSTER)] \& } \\
\text { PREY)] SW }\end{array}$ \\
\hline 5 & $\begin{array}{l}\text { Identification of cross-domain } \\
\text { mapping }\end{array}$ & $\begin{array}{l}\text { target }<\text { source } \\
\text { EXPAND }<\text { GROW } \\
\text { KILL VICTIMS }<\text { SWALLOW VICTIMS } \\
\text { Inference } \\
\text { PANDEMIC KILL VICTIMS }<\text { MONSTER SWALLOW } \\
\text { VICTIMS } \\
\text { more specifically } \\
\text { PANDEMIC IS MONSTER }\end{array}$ \\
\hline
\end{tabular}

From this analysis, it may be understood that the metaphor-related words membesar and menelan infer the conceptual metaphor PANDEMIC IS MONSTER. This reaches past the dictionary definition of "an imaginary creature that is very large, ugly and frightening", or even the metaphoric "something that is extraordinarily large".

Culturally, the Indonesian people understand monsters as raksasa, as the supernatural beings narrated through wayang 
stories and fairy tales. These monsters are understood as almost human in form, yet significantly larger. Indonesians recognize some supernatural as invisible, and others as astral beings (genderuwo, buta, etc.). Both tangible and intangible raksasa are inexorably linked with conflict and fear. However, intangible and astral raksasa are not as familiar with contemporary Indonesians as the physical raksasa described in wayang stories and fairy tales. As such, it is possible that the conceptual metaphor PANDEMIC IS MONSTER is a more specific form of the conceptual metaphor PANDEMIC IS GHOST/SPECTER.

The understanding of raksasa as frightening beings that threaten human life is used to create a sense of fear. There are thus semantic similarities between ghost/monster and the COVID-19 pandemic; both are framed as intangible beings that endanger human life. Further investigation is necessary, as this study is limited in its ability to explore the above-mentioned possibility.

\section{Metaphors' Function as Rhetoric Devices in Persuasive Discourses}

This section will examine the diverse functions of metaphors in persuasive discourses, as represented by the press releases issued by Lapor COVID-19 and Kominfo. Functional analysis has been conducted to understand the link between the basic and contextual meanings of the collected data.

Table 9. Analysis of the Metaphors' Function

\begin{tabular}{|c|c|c|c|c|}
\hline No & Metaphor & Basic Meaning & $\begin{array}{c}\text { Contextual } \\
\text { Meaning }\end{array}$ & Function \\
\hline 1 & berguguran & $\begin{array}{l}\text { 'to die in battle, } \\
\text { often in large } \\
\text { numbers' }\end{array}$ & $\begin{array}{l}\text { 'many have died while } \\
\text { treating COVID-19 } \\
\text { patients' }\end{array}$ & $\begin{array}{l}\text { to increase interest and } \\
\text { stimulate the imagination }\end{array}$ \\
\hline 2 & berdamai & $\begin{array}{l}\text { 'to reconcile after a } \\
\text { period of enmity' }\end{array}$ & $\begin{array}{l}\text { 'to adapt one's } \\
\text { behavior to new } \\
\text { healthcare protocols to } \\
\text { stop the spread of } \\
\text { COVID-19' }\end{array}$ & $\begin{array}{l}\text { reduce the complexity of } \\
\text { the message }\end{array}$ \\
\hline 3 & garis depan & $\begin{array}{l}\text { 'a line of defense } \\
\text { situated in close } \\
\text { proximity the } \\
\text { enemy (in battle)' }\end{array}$ & $\begin{array}{l}\text { 'an area defending } \\
\text { against COVID-19; } \\
\text { hospital' }\end{array}$ & to concretize \\
\hline 4 & melawan & $\begin{array}{l}\text { 'to face off against } \\
\text { during war' }\end{array}$ & $\begin{array}{l}\text { 'to prevent, to } \\
\text { eradicate' }\end{array}$ & $\begin{array}{l}\text { to increase interest and } \\
\text { stimulate the imagination }\end{array}$ \\
\hline 5 & menang & $\begin{array}{l}\text { 'defeat enemies, } \\
\text { opponents, } \\
\text { competitors' }\end{array}$ & $\begin{array}{l}\text { 'successfully stop and } \\
\text { eradicate COVID-19' }\end{array}$ & $\begin{array}{l}\text { to increase interest and } \\
\text { stimulate the imagination }\end{array}$ \\
\hline 6 & benteng & $\begin{array}{l}\text { 'a building used to } \\
\text { protect or defend } \\
\text { against enemy } \\
\text { attacks' }\end{array}$ & $\begin{array}{l}\text { 'immunity from COVID- } \\
19 \text { ' }\end{array}$ & to concretize \\
\hline 7 & menghantui & $\begin{array}{l}\text { 'to spook as a } \\
\text { ghost/specter' }\end{array}$ & $\begin{array}{l}\text { 'to cause fear (concern, } \\
\text { anxiety); to frighten' }\end{array}$ & $\begin{array}{l}\text { to increase interest and } \\
\text { stimulate the imagination }\end{array}$ \\
\hline 8 & membesar & $\begin{array}{l}\text { 'to become big; to } \\
\text { appear big' }\end{array}$ & $\begin{array}{l}\text { 'to spread more } \\
\text { broadly' }\end{array}$ & $\begin{array}{l}\text { to increase interest and } \\
\text { stimulate the imagination }\end{array}$ \\
\hline
\end{tabular}




\begin{tabular}{|c|l|l|l|l|}
\hline 9 & menelan & $\begin{array}{l}\text { 'to take (food) } \\
\text { through one's } \\
\text { throat' }\end{array}$ & 'to consume prey, etc.' & $\begin{array}{l}\text { to increase interest and } \\
\text { stimulate the imagination }\end{array}$ \\
\hline
\end{tabular}

Several of the metaphoric expressions used in press releases, including berguguran, berdamai, melawan, menang, menghantui, membesar, and menelan, are categorized as verbs. Kristina (2017, p. 91-95) notes that verbs are highly persuasive, as they give the impression of movement and action. The usage of verbs transforms how arguments are read, as well as increase their persuasiveness (Carpenter and Henningsen, 2011, p. 53). It appears that these metaphors are used as rhetoric devices to increase the persuasiveness of the texts.

The word berguguran is a metaphoric expression that is used to increase the attractiveness of the message and to stimulate readers' imaginations. Berguguran is a conventional metaphor, one that has long been used in the war domain. In readers, it triggers the image of soldiers fighting and dying on the battlefield. The frightening and threatening connotations of war are used as persuasive devices to increase readers' emotional response. In this text, the word berguguran is used in conjunction with tenaga kesehatan (health professionals), and in doing so serves to draw readers' empathy in response to the conditions experienced by said professionals. At the same time, the word berguguran honors the dead health professionals, as it implicitly likens them to soldiers or heroes who have been killed in the line of duty. This message may increase readers' awareness of the dangers of COVID-19 and the ongoing emergency situation.

The word berdamai is a metaphoric expression used to reduce the complexity of the message within its specific context. It is transformed from the basic meaning 'to reconcile after a period of enmity', taking on the meaning 'to adapt one's behavior to new healthcare protocols to stop the spread of COVID-19'. In this example, the word berdamai is simpler and more easily understood than the technical concepts "new behavior", "health protocol", and "stop the spread of COVID-19".
The word berdamai also has positive and inclusive connotations, implying "stability", "calm", and "serenity". However, where novel metaphors are used, they may be misunderstood. This is anticipated in the following quote:

"Saya ingin menekankan bahwa berdamai bukan berarti menyerah. Berdamai adalah menyesuaikan diri dengan kedisiplinan yang tinggi untuk menjalankan protokolprotokol kesehatan sebagai upaya untuk memutus mata rantai penyebaran COVID19."

(I want to emphasize that making peace is not surrendering. To make peace is to adapt oneself to health protocols, with a high level of discipline, and thus break the transmission chain of COVID-19).

(Source: https://www.kominfo.go.id)

Because this metaphor is a new one, it may be interpreted diversely by the public. The word berdamai may be misinterpreted, for example, as 'surrender'. Recognizing this possibility, the Kominfo press release seeks to control and shape public opinion by imparting audiences with an explicit understanding: berdamai means adapting one's behaviors to health protocols, thereby stopping the spread of COVID-19.

A different perspective is evident in a press release, titled "Bukan Berdamai, Tapi Berjuang Bersama Melawan COVID-19" (Do Not Make Peace, but Fight Together Against COVID-19). In this release, it is evident that Lapor COVID-19 does not agree that it is necessary to "make peace", not because the organization understands berdamai differently, but because of factual data on the government's handling of the COVID-19 pandemic. Consider the following quote: Melihat dinamika ini, Pemerintah
Indonesia telah meminta masyarakat
untuk mengubah perilaku dan 
menyesuaikan diri dengan berdamai dengan virus korona baru ini. Dalam siaran pers pada Sabtu (16/5), Juru Bicara Gugus Tugas Achmad Yurianto mendefinisikan, pola hidup baru itu di antaranya agar masyarakat agar melakukan kehidupan normal, yang diimbangi dengan upaya membiasakan untuk mencuci tangan dengan sabun, menggunakan masker, menghindari kerumunan, dan tidak keluar rumah jika tidak perlu.

(Seeing these dynamics, the Indonesian Government has asked the people to change their behavior and adapt themselves to make peace with the novel coronavirus. In a press release issued Saturday (16/5), Spokesman Achmad Yurianto defined this new lifestyle as requiring people to continue life as normal, with some changes: handwashing, with soap; wearing a mask; avoiding crowds; and not leaving home unnecessarily.

(Source: https://laporcovid19.org)

In this quote, Lapor COVID-19 reproduces the meaning of the word berdamai offered by the government: to change one's behavior and adapt oneself. This press release also quotes Achmad Yurianto, the spokesman of the COVID-19 Eradication Unit, regarding the new lifestyle necessitated to weather the pandemic. In its discourse, Lapor COVID-19 rejected the call to berdamai, arguing 1) the state must prepare itself, and prioritize health services before reopening the economy in a new normal' condition, 2) the Indonesian government had limited data, and it was not conveyed transparently, and this limited the government's ability to curb the spread of COVID-19, and 3) widespread COVID-19 testing had yet to occur. It used these three arguments to assert that Indonesia was not yet ready to begin the "new normal". Instead of berdamai, it offered the word melawan ('oppose') in its persuasive discourse. This word underscores that Lapor COVID-19's objections stem not from its understanding of the metaphoric expression, but rather its perception that Indonesia was not ready to begin a 'new normal'.

The word garis depan has the basic meaning 'a line of defense situated in close proximity the enemy (in battle)'. This conventional metaphor is used as a concrete reference, something that can facilitate readers' understanding of the contextual meaning and visualization of the involved spaces. The word garis depan, which is commonly used in military contexts, is a strong visual that guides readers towards an understanding of hospitals' strategic position in the treatment of COVID-19, as well as the urgency of such treatment.

The word melawan has the basic meaning 'to face off against during war', but is used to convey the contextual meaning 'to prevent, to eradicate'. It is intended both to increase reader interest and to stimulate readers' imaginations. In the sentence "Kiranya benang merah antara ibadah puasa dan Lebaran ini juga sesuai dengan semangat kita melawan COVID-19 ini, yaitu laku menahan diri, menempa raga, membersihkan diri, dan pada akhirnya mencapai kemenangan." the word melawan is associated with the words semangat (passion), menempa (temper), diri (self), raga (body), and kemenangan (victory). Using such words, this discourse emphasizes only positive connotations. The word melawan is also used to stimulate readers' imaginations, to empower them to fight and achieve victory. This metaphor is identified in five press releases on the Kominfo website. This repetition shows not only that Kominfo has sought to give readers the necessary spirit to stop the spread of COVID-19, but also that the government has relied heavily on the word melawan. This message was used to motivate readers, so that they would contribute to the eradication of COVID-19.

The word menang has the basic meaning 'to defeat enemies, opponents, competitors'. In the sentence "Saya yakin dan percaya, bersama, kita menang dari corona atau COVID$19, "$ the word menang has the contextual meaning 'successfully stop and eradicate COVID-19'. The use of the words yakin ('certain'), percaya ('believe'), bersama ('together'), and kita ('we') in conjunction with menang, showing an emphasis on positive connotations. It presents the eradication of COVID-19 as a joint project, and in doing so seeks to persuade readers to work together 
during the pandemic, to 'win' by stopping the spread of COVID-19.

The word benteng is a metaphoric expression used to indicate 'immunity', as seen in the sentence "Karena saat ini imunitas tubuh menjadi benteng pertahanan utama dari tubuh kita untuk melawan COVID-19." It concretizes immunity as something capable of defending against COVID-19's attacks on the human body. This metaphoric expression leads readers to imagine immunity as a physical object, and thereby to better visualize its role in the pandemic. In this manner, the discourse seeks to motivate readers to strengthen their immune systems so they can avoid COVID-19.

The word menghantui is a metaphoric expression that can increase reader interest and stimulate readers' imaginations. In the sentence "Ancaman infeksi COVID-19 juga menghantui para pekerja perkantoran dan industri di Indonesia," the metaphoric expression menghantui guides readers to imagine COVID-19 as a 'ghost' that causes fear and anxiety. These negative emotions are exploited to increase readers' empathy for Indonesia's office workers and industrial laborers while simultaneously emphasizing the need for caution.

The words membesar and menelan are both metaphoric expressions that can increase reader interest and stimulate readers' imaginations. They guide readers to imagine COVID-19 as an ever-growing threat, one capable of swallowing human beings whole. In the sentence "Pandemi COVID-19 terus membesar dan menelan banyak korban jiwa, serta menimbulkan masalah ekonomi", the words membesar and menelan are combined to frighten readers by underscoring the spread of the deadly disease. It refers to the pandemic as a 'monster', or, in the Indonesian socio-cultural sphere, a raksasa, and in this manner emphasizes the danger of the ongoing pandemic.

\section{Conclusion}

This study has found nine linguistic metaphors used to refer to the COVID-19 pandemic, namely 1) berguguran ('fall in battle'), 2) berdamai ('make peace'), 3) garis depan ('frontlines'), 4) melawan ('oppose'), 5) menang ('win'), 6) benteng ('fortress, bastion'), 7) menghantui ('spook'), 8) membesar ('grow in size'), and 9) menelan ('swallow'). Lapor COVID-19 used these metaphors in three domains: PANDEMIC IS WAR, PANDEMIC IS GHOST/SPECTER, and PANDEMIC IS MONSTER. Meanwhile, Kominfo used metaphors in one domain: PANDEMIC IS WAR.

This distinction may be attributed to Lapor COVID-19's use to voice the interests of the public. The metaphoric expressions used in its press releases were intended to increase the public's sensitivity to the pandemic. In this, it used metaphors such as menghantui, membesar and menelan, all of which are common in disaster discourses (including pandemic discourses). These metaphors were also made possible by Lapor COVID-19's relative freedom in its discourses.

Meanwhile, the governmentrepresented here by Kominfo-had a vested interest in maintaining domestic stability and security. As such, it relied heavily on the conceptual metaphor PANDEMIC IS WAR, which it deemed the most appropriate and strategic means of communicating the state's policies and guiding Indonesians through the COVID-19 pandemic.

It may thus be concluded that, in both cases, institutions' choice of conceptual metaphor was heavily informed by their particular characteristics and the discursive genres used. The government used metaphors to reduce the complexity of its message while stimulating readers' interest and imaginations. Lapor COVID-19, meanwhile, used metaphors to stimulate readers' interest and imaginations while simplifying and concretizing its message. It may thus be concluded that the persuasive discourses offered by Lapor COVID-19 and Kominfo used metaphors to 1) increase reader interest and stimulate readers' imaginations, 2 ) reduce the complexity of their message, and 3) concretize their message. These metaphors' persuasive power was used to shape readers' emotional and rational responses. 


\section{References}

Boeynaems, A. Burgers, C., Konijn, E. A., \& Steen, G. J. (2017). The impact of conventional and novel metaphors in news on issue viewpoint. International Journal of Communication, 11(2017): 2861-2879.

Carpenter, C. J., \& Henningsen, D. D. (2011). The effects of passive verb-constructed arguments on persuasion. Communication Research Reports, 28(1), 52-61.

Courtright, J., \& Smudde, P. (2009). A genre perspective on public relations message design. In 12th International Public Relations Research Conference: Research That Matters to the Practice (pp. 146162). Florida: Institute for Public Relations.

Haula, B., \& Nur, T. (2019). Konseptualisasi metafora dalam rubrik opini Kompas: kajian semantik kognitif. RETORIKA: Jurnal Bahasa, Sastra, dan Pengajarannya, 12(1), 25-35.

Kristina, D. (2017). Bahasa Persuasif dalam Public Relations. Jakarta: Akademi Indonesia Sekolah Darurat Kartini.

Lakoff, G., \& Johnson, M. (1981). Metaphors We Live by. Chicago: University of Chicago Press.

Steen, G. J. (2007). Finding metaphor in discourse: Pragglejaz and beyond. Culture, Language and Representation, $V, 9-25$.

Steen, G. J. (2009). From linguistic form to conceptual structure in five steps: analyzing metaphor in poetry. In G. Brône \& J. Vandaele (eds.), Cognitive Poetics: Goals, Gains and Gaps (pp. 197-226). Berlin: Mouton de Gruyter.

Sudaryanto. (2015). Metode dan Aneka Teknik Analisis Bahasa. Yogyakarta: Sanata Dharma University Press.
Syaipudin, L. (2020). Peran komunikasi massa di tengah pandemi COVID-19: studi kasus di gugus tugas percepatan penanganan COVID-19 Kabupaten Tulungagung. Kalijaga Journal of Communication, 2(1): 14-34.

Wafa, M. A. (2020). 'Virus corona' gentayangan di jalanan Jakarta. Vlix.id. Accessed from https://www.vlix.id/ foto/news/24299lsquo-virus-corona-rsquo-gentayangandi-jalanan-jakarta on 20 November 2020.

Data

https://www.kominfo.go.id/content/detail/2 9179/siaran-pers-no106hmkominfo092020-tentangperpanjang-wfh-menkominfo-terapkan4m-dan-tetap-produktif/0/siaran pers

https://www.kominfo.go.id/content/detail/2 6685/siaran-pers-no72hmkominfo052020-tentang-gelarlebaran-virtual-kominfo-ajakmasyarakat-berdamai-dengan-pandemicovid-19/0/siaran pers

https://www.kominfo.go.id/content/detail/2 6605/siaran-pers-no70hmkominfo052020-tentang-bangkitdalam-optimisme-normalbaru/0/siaran pers

https://www.kominfo.go.id/content/detail/2 6481/siaran-pers-no68hmkominfo052020-tentang-pegawaikominfo-peduli-covid-19-sumbang-2250rapid-test-kit-dan-apd-untuk-11$\underline{\text { rs/0/siaran pers }}$

https://www.kominfo.go.id/content/detail/2 5476/siaran-pers-no51hmkominfo032020-tentang-gotongroyong-lawan-covid-19-ksp-didukungkominfo-luncurkan-aplikasi-10-rumahaman/0/siaran pers

https://www.kominfo.go.id/content/detail/2 5292/siaran-pers-no47hmkominfo032020-tentangdukungan-platform-digital-untuk-socialdistancing/0/siaran pers 
https://laporcovid19.org/kapan-kapasitasrumah-sakit-di-jakarta-kolaps/

https://laporcovid19.org/sebagian-besarpenyintas-covid-19-dan-keluarganyamendapat-stigma/

https://laporcovid19.org/agar-new-normaltidak-menjadi-new-abnormal-penuhisyarat-epidemiologi-dan-sosial/

https://laporcovid19.org/bukan-berdamaitapi-berjuang-bersama-melawan-covid$\underline{19 /}$

https://laporcovid19.org/waspada-klusterperkantoran/ 